Underground are in very densely populated districts, and so the light weight and freedom from vibration of the rectifiers enable appreciable economies to be effected on the building costs. Mr. Lunn looks forward to the time when the continued development of the railway area may lead to the changing-over of a number of existing substations to new supply networks, probably involving a change of frequency. With the present system of rectifiers this would offer no difficulty.

\section{Second-hand Electrical Plant}

THE policy of the Central Electricity Board in closing down obsolescent electricity supply stations has had the effect of crowding the machinery and equipment market with plant at very low prices. In his presidential address to the Midland Centre of the Institution of Electrical Engineers, Colonel H. C. Fraser said that this plant is being bought by industrial users, and that this is detrimental to the supply industry. The user having very small capital charges is placed in a strong position to compete with the public supply. The recent sales of electrical plant and fittings from ocean liners, such as the Mauretania and the Olympic, have also decreased to a certain extent the capital charges of the purchasers. On the other hand, mill owners and others are very reluctant to dispose of existing moderately efficient plant at scrap values. The question is one of economics. When the user has capital at his disposal, he can estimate the cost of the renovation of plant and the increase in profits that will probably ensue; and if satisfied, he should not delay the change-over too long. We think that the gain to the community effected by scrapping plant at the proper economical time far more than counterbalances the loss to manufacturers due to the consequent diminished demand for machines and equipment.

\section{Antarctic Discoveries}

Some of the more important discoveries made by Admiral R. E. Byrd's American Antarctic Expedition of 1934-35 are indicated in sketch maps accompanying an article by Admiral Byrd in the National Geographic Magazine of October. There seems now to be no probability of a sea-strait joining the Ross and Weddell Seas, a suggestion made some years ago on slender evidence. It appears that Marie Byrd Land, which lies south-east of King Edward Land, extends in a plateau of over a thousand feet, called the Rockefeller Plateau, to the base of the Queen Maud Range, which has been extended another two hundred miles eastward. At the south-eastern end of the Ross Sea a gulf extends into this plateau to about long. $140^{\circ} \mathrm{W}$. Another discovery is that the Edsel Ford ranges which lie east of the Alexandra Mountains of King Edward Land extend east and west, and suggest possible extensions of the Andean foldings of Graham Land. A third striking discovery, made by sonic soundings, is that much of the Ross Ice Barrier is aground and not afloat. South of the Bay of Whales, Admiral Byrd has tentatively marked an area of the Barrier extending between lat. $78^{\circ} 40^{\prime} \mathrm{S}$. and $80^{\circ} 20 \mathrm{~S}$. and long. $160^{\circ} \mathrm{W}$. and $164^{\circ} \mathrm{W}$. as
Roosevelt Island. This he believes to be underlaid by land. Several altitudes in this area are well above the general level of the Barrier.

\section{Science and Social Needs}

IN his Halley Stewart Trust Lecture delivered in the Memorial Hall, Farringdon Street, London, on November 21, Prof. Julian Huxley discussed "Science and Social Neods". The academic view of science is that it is "pure"-a disinterested explorer of the unknown, and thus an accumulator of organised knowledge. Opposed to this is the view that science is essentially practical, showering upon humanity gifts in the shape of inventions and technical improvements. A third view is that science, far from being beneficent, is actually an evil genius. Of course, the application of scientific methods in the mechanisation of industry may result in unemployment. But the blame does not lie with the scientific worker, but rather with the present economic system. Science is actually a tool, and is therefore ethically neutral. The tempo of scientific discovery may be too fast for modern society; but that is a matter for practical adjustment, not for moral condemnation. The true fact is that science embodies both the first and second views, in that it is both knowledge and control, pure and applied. Progress may flow either from theory to practice or vice versa.

SCIENCE is a function of society, influencing the social system and being influenced by it in return. To-day it is often frustrated-actual discoveries already made are not applied. In fact, science is prosecuted and applied much more from the angle of the producer and the State than from that of the consumer or the individual citizen. Research where an immediate profit can be discerned obtains far greater financial support than long-range research where the advantage is indirect. Prejudice too may often interfere with the use of scientific methods of analysis. This applies especially to social science, education, etc. Social forces could be scientifically analysed and controlled, and social machinery scientifically designed and planned in the same way as has been done for natural forces and industrial machinery. In order to prevent the present piecemeal or lop-sided development of science, we need a new discipline-the scientific study of science itself, in its capacity as a social function.

\section{Journal of the Institution of Civil Engineers}

WrTH the opening of the 1935-36 session, there appears the now Journal of the Institution of Civil Engineers-an occasion which marks another stage in the development of the Institution's publications, and should increase the facilities for "the acquirements of knowledge in engineering", laid down by the founders as one of its objects. Portraits of the first president, Thomas Telford (1820-34), and of Mr. John D. Watson, who now occupies this office, appear in the first number, which opens with a foreword by Mr. Watson and an interesting account of the origin and progress of the Institution. Then follows the presidential address for the current 